E. B. Gridina, orcid.org/0000-0002-7265-1115, S.V. Kovshov, orcid.org/0000-0003-4882-4714,

T. I. Antonenko, orcid.org/0000-0002-3788-4204, A. K. Miroshnichenko, orcid.org/0000-0002-3858-8298
Saint Petersburg Mining University, Saint Petersburg, Russian Federation, e-mail: Gridina_EB@nuos.pro

\title{
DEVELOPMENT OF FIRE SAFETY MEASURES AIMED AT PREVENTING AND RESPONDING TO SPONTANEOUS COMBUSTION IN BROWN COAL MINES
}

Purpose. The problem of the occurrence of foci of self-heating, which subsequently lead to spontaneous combustion, i.e. to endogenous fires, is one of the most urgent problems in coal mines today, requiring immediate resolution. The purpose of the paper is to develop fire-technical measures for the prevention of spontaneous combustion of brown coal.

Methodology. The leading research methods for this problem are the method of analysis of scientific literature and the method for evaluating measures aimed at preventing endogenous fires, their timely recognition and localisation of an existing fire.

Findings. For the prevention and localisation of endogenous fires, measures are necessary that will allow them to be detected in a timely manner at the initial stages and begin the process of extinguishing at the very centre of spontaneous combustion, not allowing an increase in the scale of the fire. After reviewing all the measures available today, it was found that one of the most appropriate and economically viable is the use of prototypes of peat fire nozzles, which will allow extinguishing the fire directly at the initial stages of its appearance even inside the reservoir. The information obtained as a result of the analysis of scientific literature proves that fires at coal mines pose a great threat to both the technological process and neighbouring settlements.

Originality. The novelty of the study is determined by the fact that the application of modern preventive measures is objectively preferable to directly extinguishing the already existing focus.

Practical value. The value is determined by the need to introduce modern fire-fighting measures, since many theoretical aspects for the further proposal of measures have not been elaborated in sufficient quantities.

Keywords: brown coal, endogenous fire, coal mine, flame retardant, fire nozzle, combustible substances, protection methods

Introduction. The issue of the occurrence of endogenous fires in coal mines and their prevention is currently very urgent. Underground endogenous fires pose a significant danger to workers in coal mines due to the release of a large amount of toxic gases into a limited volume of air, as well as an increase in the temperature of air and rocks. In addition, underground fires can initiate ignitions and explosions of accumulations of combustible gases and coal dust. Every year, the problems of preventing and eliminating endogenous fires in waste dumps in the context of increased attention to ecology and production safety are becoming increasingly important. In recent years, during open pit mining, endogenous fires have been the most common accidents and accounted for about $39 \%$ of their total number [1, 2]. Despite the relevance of this issue and the long history of its research, many theoretical aspects for the further proposal of measures have not been sufficiently elaborated.

An effective fight against spontaneous combustion is impossible without the use of methods for detecting spontaneous combustion at an early stage of development, as well as monitoring the state of foci of spontaneous combustion. Only the solution of these problems will improve the safety of mining operations and reduce the economic damage caused by endogenous fires. However, the difficulty of detecting and then extinguishing endogenous underground fires is due to the fact that in most cases they are inaccessible to people. The most difficult situation arises with the practical necessity of introducing fire-prevention measures. In the best case, the procedure for the formation of dumps and preventive measures should prevent fires. In addition, the fires that have arisen in some cases are allowed to take their course, and their extinguishing begins only under the direct pressure of environmental authorities and structures that control industrial safety. The

(c) Gridina E. B., Kovshov S. V., Antonenko T. I., Miroshnichenko A. K., 2020 methods for combating endogenous fires existing in coal mines are either laborious or ineffective and, in most cases, do not exclude the loss of mineral resources and the possibility of reoccurrence [3, 4].

Endogenous fires, as a rule, can occur in the worked-out areas of mines, as well as during open-pit mining on the slopes of coal mines. The main cause of endogenous fires is self-heating followed by spontaneous combustion of coal. Spontaneous combustion can cause great losses and cause great damage to human lives. When in contact with the air, accumulations of combustible minerals (peat, coal, sulphurous ores) and some other materials (for example, sawdust, hay, etc.) sometimes spontaneously increase their temperature - the so-called selfheating. Having reached a critical value (usually $70-80^{\circ} \mathrm{C}$ ), it can progress rapidly and cause the ignition of these fossils and materials.

Due to the formation of a large amount of heat during the oxidation of a substance, it does not have time to dissipate in the external environment, this is what causes self-heating. As the oxidation temperature rises, heat transfer also begins to increase [5]. Cooling begins only when thermal equilibrium is established, after which heating usually ceases. Combustion is achieved under the condition of heating and increasing temperature, with heat transfer to the external environment. A similar phenomenon is achieved only under certain conditions [6].

The information obtained as a result of the analysis of scientific literature and real experience of open-pit mines operation makes it possible to understand that fires at coal mines pose a great threat to both the technological process, the ecological system and personnel, and nearby settlements, therefore, the problem of prevention and elimination of endogenous fires is relevant in modern times and requires an early solution.

Purpose. The aim of the study is to develop fire-technical measures for the prevention of spontaneous combustion of brown coal. 


\section{Research tasks:}

- analysis of scientific literature in order to study existing measures for the prevention and localisation of endogenous fires;

- determination of the most effective, feasible and economically-viable way to prevent and localise endogenous fires;

- development of methods that make it possible not only to identify combustion processes, but also help to localise the combustion source, and also allow assessing the scale of the problem in order to select the most optimal direction for eliminating a fire.

Literature review. To analyse the current situation related to the development of fire-technical measures for the prevention and elimination of foci of spontaneous combustion of brown coal, scientific papers and studies, as well as patent documentation published by such authors as I. A. Arkhipov and A.E. Filin [1], E.S.Safin and K. E. Kiryanova [4], A. Yu. Petrov and Yu. D.Smirnov [7], Chemezov E. N. [8], V. A. Portola [9], and others were considered. The abundance of scientific and patent information speaks of the urgency of the problem and the variety of proposed methods for its solution.

Petrov A. Yu. and Smirnov Yu. D. [7] consider the issue of the negative impact of coal fires on the atmospheric air due to the release of a large amount of harmful substances in the form of sulfur dioxide and carbon monoxide. The most applicable methods and means of extinguishing and prophylactic treatment of coal seams to prevent endogenous fires (using water and solutions (antipyrogens), using inert materials) are also considered. The authors propose an alternative way to eliminate the foci of endogenous fires - filling the mine with stowing material from the processing plants of nearby enterprises.

The paper by V.A. Portola, A. N. Zhdanov and A. A. Bobrovnikova [10] also discusses the method of using antipyrogens to eliminate and prevent endogenous fires. To increase the incubation period of spontaneous combustion, it is proposed to use the addition of water to the coal accumulation, as well as to reduce the rate constant of oxygen sorption by coal. The authors believe that the most acceptable way to prevent the occurrence of endogenous fires during storage of coal in stacks is to reduce the amount of oxygen absorbed by coal, which will directly lead to a reduction in heat generation. At the same time, additional heat losses for heating and the formation of liquid vapors carried out into the surrounding space will also occur. According to their experiment, the duration of the incubation period can be controlled by both the selection of the antipyrogen and the amount of aqueous solution used to treat coal storages.

The paper by Yu. N. Shaposhnik, A. I. Konurin, D. A. Shokarev and S. N. Shaposhnik [11] describes in detail the possibility of using foamed phenolic resin as backfilling of the anchorage space, which will reduce the intensity of the oxidation reaction and prevent self-heating of ore to critical temperatures, as well as prevent or slow down the process of heating the mine air from the heated surface of the ore mass to temperatures exceeding the standard values.

Moving on to the topic of patents, it should be noted that many of them offer various ways to prevent or extinguish endogenous fires not only of coal, but also of peat deposits.

In the formula of patent No. 2573493, the authors of which are D.A.Trubitsyn and A. A. Trubitsyn, "A method for preventing the occurrence of endogenous fires", a method was proposed for preventing the occurrence of endogenous fires, including the treatment of the surface of the coal. In this case, the surface of the coal is pretreated with a sticky liquid, and then microcapsules from a non-heat-resistant and water-insoluble material with a diameter of 20 to $5000 \mu \mathrm{m}$ are sprayed under pressure, containing an inhibitor in an amount of 50$95 \%$ and easily opening at temperatures above 45 degrees [12].

Patent No. 2640178, by V. I. Zabegaev and N. P. Kopylov "Method for extinguishing local foci of combustion of peat fires". The invention relates to methods for extinguishing local underground foci of combustion of peat fires in conditions of limited use of heavy machinery, equipment and the risk for workers. The essence of the proposed method lies in the initial determination of the boundaries of the active focus of combustion of a peat fire in the form of an underground chamber, the subsequent drilling of inclined wells in the direction of the named chamber and the supply of water under pressure to the combustion zone of the underground chamber of the peat layer. To implement the method, it is necessary to mount downhole hydromonitors with a nozzle in the front part, followed by washing out of the said nozzle of the peat layer with water by circular rotation of the downhole hydromonitor with a rotary mechanism and mechanical mixing of burning and non-burning peat layers until the fire is completely extinguished. This method for extinguishing local underground foci of peat fires is easy to operate and can be used to extinguish local peat fires with any depth of peat occurrence in conditions of limited use of heavy machinery, equipment and the risk of people staying [13].

Based on all of the above, it can be concluded that a high endogenous fire hazard leads to a continuous search for new and improvement of already used methods, documentation and means in the field of prevention and prediction of endogenous fire occurrence. Unfortunately, traditional technologies have financial and environmental constraints that greatly impede the process of eliminating this important problem, which in turn affects not only the financial part or the environment, but also the health of employees of the coal industry.

In the course of analysing the information received and predicting possible measures for the prevention and elimination of endogenous fires, it would be most rational, in the authors' opinion, to take the method for extinguishing peat fires using peat fire shafts as a basis. With its help, much less effort can be spent on the process of reaching the source of spontaneous combustion due to the screw blades in the structure of the peat fire nozzle.

The method itself is described in more detail in the paper by S.V. Shirobokov，R. I. Skorobogatova， R. I. Sidriev and S. Yu. Zagumenov "Nozzle for extinguishing peat fires" [14]. In this paper, the idea of reducing the hydrodynamic load on peat shafts when extinguishing peat fires was developed. It is assumed that if from 10 to 20 peat shafts are connected in series and, by means of pressure regulator valves pre-installed on each shaft, evenly distribute the flow of extinguishing agent into the soil, then with the help of the auger blades built into the structure, it becomes possible to cut solid rock during digging-in, holding it in an upright position and opening free channels to bring excess fluids to the surface. Due to this, the likelihood of pushing out the nozzle under the pressure of the extinguishing agent is significantly reduced. As a result, it becomes possible to release authorised workers from constant duty at the shafts and bring the process of extinguishing an endogenous fire to automation.

Since this method is the safest for the employees involved in the elimination and prevention of the spontaneous combustion source, and also based on the calculations it is considered the least costly, it makes sense to consider it as a possible preventive or liquidation measure for the conditions of a particular mining enterprise discussed in the paper.

Methods. The set of measures that are aimed at preventing fires and reducing their size is usually called fire prevention. In the fight against mine fires, a number of main tasks have been identified: prevention of a fire; ensuring the possibility of rescuing people who will be caught in a fire in underground workings; ensuring the possibility of localising the fire that has arisen and facilitating its complete elimination.

Table 1 shows the numeric distribution of accidents that occurred at coal enterprises in Russia.

In accordance with the objectives, preventive measures are very diverse, but mainly consist of the following: 
Numeric distribution of accidents at coal enterprises in Russia for 2017 and 2018

\begin{tabular}{|l|c|c|}
\hline \multirow{2}{*}{ Accident type } & \multicolumn{2}{c|}{ Year } \\
\cline { 2 - 3 } & 2017 & 2018 \\
\hline Total & 19 & 12 \\
\hline Endogenous fires & 3 & 2 \\
\hline Exogenous fires & 7 & 5 \\
\hline Gas accumulation in mine workings & 0 & 0 \\
\hline Explosions and ignition & 2 & 0 \\
\hline Cavings and collapses & 0 & 0 \\
\hline Water breakouts and flooding & 2 & 1 \\
\hline Gas breakthroughs from areas with fires & 0 & 1 \\
\hline Landslides and collapses & 5 & 3 \\
\hline
\end{tabular}

1. Measures that eliminate the immediate or possible causes of fires. These measures can be divided into groups: impact on technological processes in order to preserve fire safety (selection and use of the safest development system in terms of completeness of fossil fuels extraction); technical nature of measures (ventilation reversibility, correct installation of electrical equipment).

2. Measures that limit the spread of the resulting fire. This group mainly includes construction and technical methods of fire protection, such as, for example, proper planning of buildings and structures on the surface of the mine, the use of noncombustible structures in mine construction, the device of special barriers in the form of fire-prevention bratticing, fireproof doors, fire protection areas.

3. Measures that ensure the successful evacuation of people (rescue of workers) from the mines caught in the fire.

4. Measures that ensure the rapid and timely deployment of tactical actions of mine rescue and auxiliary firefighting teams. The latter include: the device of special passages to hard-to-reach places, the equipment of fire-fighting bases, in particular, mobile ones, both on the surface and underground [15].

For the purpose of prevention, the following technological measures are also envisaged, which exclude or significantly reduce the possibility of spontaneous combustion:

- systematic renewal of coal ledges before the start of their spontaneous combustion;

- thorough cleaning of loosened coal from all elements of the coal ledges (upper edge, slope and working platforms);

- placement of rock-coal rock mass and sooty coal in the lower dump tier, isolation with inert rock;

- a ban on the use of loosened rock mass containing spontaneously combustible materials as a basis for road filling;

- timely detection of self-heating foci by visual observations and instrumental measurements in potentially fire hazardous places;

- shipment of cooled coal;

- ensuring a more complete extraction of coal prone to spontaneous combustion [15].

Also, a special group of preventive measures is the use of antipyrogens. Antipyrogen is a substance that prevents a process of spontaneous combustion of a fossil in quarries, in dumps. The effect of the antipyrogen is aimed at reducing the activity of reactions on the occluding surface of minerals or reducing the surface area [7]. Liquid nitrogen, argon, helium in the form of a gas or an easily evaporating liquid can be used as antipyrogens, and also as antipyrogens are used: aluminium sulphate solution, ammonium phosphate solution, lime solution, ammonium phosphate. It should be noted that the treatment of coal with antipyrogens, which reduce the chemical activity of coal relative to oxygen, is the most popular way to prevent the occurrence of endogenous fires.

Currently the used methods for extinguishing endogenous fires are divided into two types: active and passive. Recently, passive fire protection measures have been increasingly used at enterprises, production and industrial facilities. Such measures are implemented without human intervention and the elimination of the cause of the fire occurs as soon as possible $[8,16]$. Passive methods include covering the quarry walls with antipyrogens, which were mentioned above.

The active extinguishing methods include the actual extinguishing of the fire itself. If a fire breaks out in the quarry areas where the atmosphere was contaminated with combustion products, the work must be stopped, except for activities associated with the elimination of the fire and its source of ignition.

Active extinguishing methods that can achieve the flame suppression include the following:

- directly stopping the access of oxygen (oxidiser) or a combustible substance to the combustion zone, as well as reducing their supply to values at which combustion becomes impossible;

- the combustion zone is cooled to values below the selfignition temperature or the temperature of the burning substance drops below the ignition temperature;

- adding non-combustible substances to combustible substances (dilution);

- inhibition of combustion, which is an intense inhibition of the rate of chemical reactions in a flame;

- mechanical stripping (separation) of the flame, which occurs with the help of a strong jet of gas or water $[9,17]$.

Results. It is commonly known that brown coal is a transitional form from peat to bituminous coal, formed directly from peat, which differs from bituminous coal in a lower amount of carbon and a significantly higher content of bituminous volatiles and water in its composition. Therefore, it can be concluded that measures to localise the centres of spontaneous combustion and all further measures to extinguish brown coal can be carried out on the basis of extinguishing peat fires [18]. Thus, it would be most logical and expedient to propose extinguishing directly into the formation by means of preliminary moistening of the formations by injecting water, solutions or clay slurry through the wells, which will prevent a fire even at the stage of self-heating and further transition to spontaneous combustion $[14,19]$.

This can be carried out with the help of fire nozzles, the prototype of which will be a peat fire nozzle. These fire nozzles are a fire-technical unit. Their main purpose is to extinguish fires by distributing the required flow of fire extinguishing compounds over the formation. The result of such extinguishing is the fact that the wetting agent is fed through the holes directly into the combustion source, and not to the surface.

In order for this measure to function correctly, the complete set of equipment for the implementation of the engineering and technical measures is presented in Table 2.

A simplified methodology for assessing the economic indicators of the implementation of the measure is presented below. $P$ is the total cost of a fire-technical measure.

Table 2

Equipment for the implementation of engineering and technical measures

\begin{tabular}{|l|c|}
\hline \multicolumn{1}{|c|}{ Name } & Quantity, pcs. \\
\hline Pipe manifold & 1 \\
\hline Fire nozzle & 15 \\
\hline Extension pipe & 15 \\
\hline Fire hose & 1 \\
\hline
\end{tabular}




$$
P=P s t v+P c o m+P n o z+P p+P m p,
$$

where $P s t v$ is a price for the required number of extension pipe; $P c o m$ is a price for the required number of pipe manifolds; is a price for the required number of fire nozzle; $P p$ is a price for the required number of fire hoses; $P m p$ is a cost of a portable motor pump.

The price for the required number of extension pipes is calculated

$$
P s t v=P 1 s t v+N s t r,
$$

where $P 1 s t v$ is a price for one extension pipe; Nstv is the required number of extension pipes.

For this device to function properly, pipe manifolds are required, which are a six-way bore for the nozzle. Price for pipe manifolds

$$
\text { Pcom }=\text { P1com }+ \text { Ncom, }
$$

where $P 1$ com is a price for 1 pipe manifold; Ncom is the number of pipe manifolds. The price for fire nozzles is calculated

$$
\text { Pnoz }=\text { P1noz }+ \text { Nnoz, }
$$

where $P 1 n o z$ is a price for one fire nozzle; Nnoz is the required number of fire nozzles. The price for fire hoses is calculated

$$
P p=P 1 p+N p,
$$

where $P 1 p$ is a price for one fire hose; $N p$ is the required number fire hoses.

Let us calculate the cost of this economic measure by the method proposed above, based on the cost indicated in the catalogues [20]. According to the data on fire nozzles, each must include a number of components (Table 3 ).

The average price of one set is about 3-4 thousand RUB. Since in this fire-technical measure, it is necessary to use from 10 to 20 fire nozzles, for the cost-to-use analysis, the average value of 15 fire nozzles is taken. Thus, the average price for the implementation of this measure will be approximately 217 thousand RUB, which is not a big spending in terms of financial costs in the mining industry.

For the estimations, a TS- $1 \mathrm{~d} .50$ peat nozzle was chosen; it can be combined with a GR-6 pipe manifold. This fire nozzle is designed to extinguish peat fires and allows applying both a compact jet to extinguish the top fires and, having penetrated into the burning rock layer, suppress the fire from the inside at a depth of more than $1 \mathrm{~m}$ at the combustion source. It also has a collapsible design and consists of a d.19 hollow metal tube, handles, a tap and a d.50 coupling head. The bottom of the hollow tube has holes up to $3 \mathrm{~mm}$ in diameter. Water with a wetting agent flows from the pump into the nozzle and through the holes into the soil under a pressure of 3-4 atm.

It is also necessary to purchase extension pipe for fire nozzles. They are hollow metal pipes with a diameter of $19 \mathrm{~mm}$; are intended to increase the length of peat nozzles; when connected, the total length is more than $2 \mathrm{~m}$.

For the system to function, the GR-6 pipe manifolds are required. They are a six-way branching for TS-1 nozzles; designed to divide the flow of supplied water when extinguishing fires; it is used in fire trucks and fire pumps.

Table 3

Fire nozzle components

\begin{tabular}{|l|c|}
\hline \multicolumn{1}{|c|}{ Name } & Quantity, pcs. \\
\hline Handles & 2 \\
\hline Valve & 1 \\
\hline Coupling head & 1 \\
\hline Tip & 1 \\
\hline Metal pipe with holes & 1 \\
\hline
\end{tabular}

The last component of this system was the fire hose d.50 RPM(P)-50-1,6-IM-UHL1 "Rubberised". This type of fire hose is considered one of the most popular, due to the modernity of the material. In terms of resistance to external influences, this hose is of special design - wear-resistant; it can be operated in temperate and cold climates.

Using the formulas presented above and the prices obtained from the catalogue [20], it is possible to determine the approximate price for the implementation of this measure, which will be approximately 90 thousand RUB, which is not a big spending, in terms of financial costs in the mining industry.

In general, it can be concluded that this measure can be recommended for mining enterprises with similar problems. Nevertheless, it should be borne in mind that preventive measures in any situation will be more preferable and recommended in real conditions in comparison with measures to combat existing combustion.

To implement modern approaches to the problem, adequate and appropriate methods for monitoring the first signs of endogenous fires and preventing their spread are needed. Also, special attention should be paid to labour protection measures for employees associated with the elimination of fire processes. Such instructions should be up-to-date and be accompanied by standards of operations in order for employees to clearly understand the factors and professional risks that they may face when performing this type of work.

Conclusions. The studies on the self-heating process, which under certain conditions leads to spontaneous combustion, made it possible to find out that the best way to localise the sources of spontaneous combustion is the use of cooling and extinguishing systems.

1. By evaluating the measures directly aimed at preventing endogenous fires, their timely recognition and localisation of an already started fire, it was proposed to decide on a fire extinguishing device based on a nozzle designed to extinguish peat fires.

2. This device is advisable because of preliminary moistening of the formation by injecting water, solutions or clay slurry through the wells directly into the formation, which will prevent a fire even at the stage of self-heating and further transition to spontaneous combustion.

3. Regardless of the fact that the economic assessment of this measure indicated that it is not financially critical for the mining industry, the analysis of preventive measures convincingly proves that the use of modern preventive measures is objectively preferable to the actual extinguishing of an already emerging focus.

4. The preventive methods for fighting endogenous fires include such innovative methods as the use of thermal imagers built into a flying drone (quadcopter) and gas analysers. The use of this alternative method will make it possible to control the thermal state and gas regime of the dump, and when the first signs of fire appear in the early stages, it provides an opportunity to take timely measures to prevent spontaneous combustion.

5. The use of these methods makes it possible not only to identify combustion processes, but also helps to localise the source of self-heating and combustion in the most accurate way, and also allows assessing the scale of the problem in order to select the most optimal direction for extinguishing a fire and can be recommended for active use in mining companies with similar problems.

\section{References.}

1. Arkhipov, I.A., \& Filin, A. E. (2019). Analysis of accident conditions at coal enterprises of Russia. Mining Information and Analytical Bulletin, (1), 208-215.https://doi.org/10.25018/02361493-2019-01-0-208-215.

2. The official website of Rostekhnadzor (2019). Retrieved from http://www.gosnadzor.ru/activity/control/list.

3. Types of accidents in opencast mining (2019). Retrieved from https://studopedia.org/. 
4. Safina, E. S., \& Kiryanova, K. E. (2018). Mineral spontaneous combustion as sources of endogenous fires. In: Ecological and Technosphere Safety of Mining Regions: Proceedings of the VI International Scientific and Practical Conference, (pp. 262-267). Yekaterinburg: Institute of Economics, Ural Branch of the Russian Academy of Sciences, Ural State Mining University. Retrieved from http://science.ursmu.ru/upload/doc/2018/06/27/3 VI mejdunarodnaya_nauchnoprakticheskaya_konferenciya_sekologicheskaya_i_tehnosfernaya bezopasnost gornopromyshlennyh regionovs.pdf.

5. Cheshkova, K. N., \& Antonenko, T.I. (2019). Theoretical aspects of the occurrence of endogenous foci of combustion in brown coal sections. In: Materials of conferences of the SRI "National Development". International Scientific Conference "Science. Research. Practice”, (pp. 72-75). St. Petersburg: Humanitarian National Research Institute "National Development". Retrieved from https://www.elibrary.ru/item.asp?id=38180927. 6. Mountain Encyclopedia (2019). Retrieved from http://www. mining-enc.ru/s/samovozgoranie-uglya.

7. Petrov, A. Yu., \& Smirnov, Yu. D. (2018). Development of protective measures to extinguish endogenous fires from spent coal mines. Modern Society: Global and Regional Processes, 5, 41-43.

8. Chemezov, E. N. (2019). Industrial safety principles in coal mining. Journal of Mining Institute, 240, 649-653. https://doi. org/10/31897/PMI.2019.6.649.

9. Portola, V.A. (2016). On the calculation of the incubation period of coal spontaneous combustion. Labor Safety in Industry, (1), 46-49.

10. Portola, V.A., Zhdanov, A.N., \& Bobrovnikova, A.A. (2019). The prospect of using antipyrogens to prevent spontaneous combustion of coal stores. Journal "Coal", (4), 14-19. https://doi.org/10.18796/0041-5790-2019-4-14-19.

11. Shaposhnik, Yu. N., Konurin, A.I., Shokarev, D.A., \& Shaposhnik, S. N. (2018). Development of technology for supporting mine under conditions of intense oxidation of sulfide ores at the Orlovsky mine. RUDN Journal of Engineering Researches, 19(2), 235-345. https://doi.org/10.22363/23128143-2018-19-2-235-245.

12. Trubitsyn, D.A., \& Trubitsyn, A.A. (2015). Method for preventing endogenous fires (RF Patent No. 2523317).

13. Zabegaev, V. I., \& Kopylov, N. P. (2016). Method of extinguishment of local peat fire combustion sources (RF Patent No. 2640178).

14. Shirobokov, S. V., Skorobogatova, R. I., Sadriev, R. I., \& Zagumenov, S. Yu. (2017). Nozzle for extinguishing peat fires. Bulletin of the Voronezh Institute of the State Fire Service of the Ministry of Emergencies of Russia, (3), 60-63.

15. Savon, D. Y., Aleksakhin, A. V., Skryabin, O. O., \& Goodilin, A. A. (2019). Occupational health and safety digitalization in the coal industry. Eurasian Mining, (2), 70-72. https:// doi.org/10.17580/em.2019.02.15.

16. Magomet, R. D., Rodionov, V.A., \& Soloviov, V. B. (2019). Methodological approach to issue of researching dust-explosion protection of mine workings of coal mines. International Journal of Civil Engineering and Technology, 10(2), 1154-1161.

17. Zhikharev, S.Ya., Rodionov, V.A., \& Pikhkonen, L.V. (2018). Innovative methods for investigating technological properties and explosion/fire risk data of coal dust. Gornyi Zhurnal, (6), 45-49. https://doi.org/10.17580/gzh.2018.06.09. 18. Rosugol (2019). Areas of application of coal. Retrieved from http://www.roscoal.ru/content/press-centr/informaciyadlya-vas/oblasti-primeneniya-uglya.

19. Moldagozhieva, Z.D., Zhilisbayeva, R. O., Kucharbaeva, K.Zh., Toktarbayeva, A. T., \& Tashpulatov, S. Sh. (2017). Development of new fire-resistant packages for welfare overalls. Izvestiya Vysshikh Uchebnykh Zavedenii, Seriya Teknologiya Tekstil'noi Promyshlennosti, 371(5), 65-69.

20. The official website of the company selling fire-fighting equipment "PozhSnab" (2019). Retrieved from https://www.pozh$\underline{\text { snabnn.ru/. }}$

\section{Розробка пожежно-технічних заходів із профілактики й ліквідації осередків самозаймання бурого вугілля}

\author{
О. Б. Грідіна, С. В. Ковшов, Т.І.Антоненко, \\ А. К. Мірошніченко
}

Санкт-Петербурзький гірничий університет, м. СанктПетербург, Російська Федерація, e-mail: Gridina_EB@ nuos.pro

Мета. Проблема виникнення вогнищ самонагрівання, що призводять у подальшому до самозаймання, тобто до ендогенних пожеж, на сьогоднішній день є однією 3 найбільш актуальних проблем на вугільних розрізах, що потребує негайного вирішення. Мета роботи полягає в розробці пожежно-технічних заходів із профілактики самозаймання бурого вугілля.

Методика. Провідними методами дослідження даної проблеми є метод аналізу наукової літератури й метод оцінки заходів, спрямованих на попередження ендогенних пожеж, їх своєчасне розпізнавання та на локалізацію вже виниклої пожежі.

Результати. Для профілактики й локалізації ендогенних пожеж необхідні заходи, що дозволять своєчасно виявити їх на початкових стадіях і приступити до процесу гасіння ще у самого вогнища самозаймання, не дозволяючи допустити збільшення масштабу пожежі. Після розгляду всіх наявних на сьогоднішній день заходів було з'ясовано, що одним з найбільш доцільних і економічно вигідних $є$ застосування прототипів торф'яних пожежних стволів, які дозволять гасити пожежу безпосередньо на початкових етапах його появи ще всередині пласта. Отримана в результаті аналізу наукової літератури інформація свідчить, що пожежі на вугільних розрізах становлять велику загрозу як технологічному процесу, так і поруч розташованим населеним пунктам.

Наукова новизна. Новизна дослідження визначається тим, що застосування сучасних превентивних заходів об'єктивно краще, ніж безпосередньо саме гасіння вже виниклого вогнища.

Практична значимість. Визначається необхідністю впровадження сучасних протипожежних заходів, оскільки багато теоретичних аспектів для подальшої пропозиції заходів не було опрацьовано в достатньому обсязі.

Ключові слова: буре вугілля, ендогенна пожежа, вугільний розріз, антипіроген, пожежний ствол, горючі речовини, способи захисту

\section{Разработка пожарно-технических мероприятий по профилактике и ликвидации очагов самовозгораний бурого угля}

\section{Е. Б. Гридина, С. В. Ковшов, Т.И. Антоненко, A. К. Мирошниченко}

Санкт-Петербургский горный университет, г. СанктПетербург, Российская Федерация, e-mail: Gridina_EB@ nuos.pro

Цель. Проблема возникновения очагов самонагревания, которые приводят в дальнейшем к самовозгоранию, т.е. к эндогенным пожарам, на сегодняшний день является одной из самых актуальных проблем на угольных разрезах, требующей незамедлительного решения. Цель работы заключается в разработке пожарно-технических 
мероприятий по профилактике самовозгораний бурого угля.

Методика. Ведущими методами исследования данной проблемы являются метод анализа научной литературы и метод оценки мероприятий, направленных на предупреждение эндогенных пожаров, их своевременное распознавание и на локализацию уже возникшего пожара.

Результаты. Для профилактики и локализации эндогенных возгораний необходимы мероприятия, которые позволят своевременно обнаружить их на начальных стадиях и приступить к процессу тушения еще у самого очага самовозгорания, не позволяя допустить увеличения масштаба возникнувшего пожара. После рассмотрения всех имеющихся на сегодняшний день мероприятий было выяснено, что одним из самых целесообразных и экономически выгодных является применение прототипов торфяных пожарных стволов, которые позволят тушить пожар непосредственно на начальных этапах его появления еще внутри пласта. Полученная в результате анализа научной литературы информация свидетельствует, что пожары на угольных разрезах представляют большую угрозу как технологическому процессу, так и рядом расположенным населенным пунктам.

Научная новизна. Новизна исследования определяется тем, что применение современных превентивных мер объективно предпочтительнее, чем непосредственно само тушение уже возникшего очага.

Практическая значимость. Определяется необходимостью внедрения современных противопожарных мероприятий, поскольку многие теоретические аспекты для дальнейшего предложения мероприятий не были проработаны в достаточном объеме.

Ключевые слова: бурый уголь, эндогенный пожар, угольный разрез, антипироген, пожсарный ствол, горючие вещества, способы защиты

Recommended for publication by V.N. Tyupin, Doctor of Technical Sciences. The manuscript was submitted 02.04.20. 